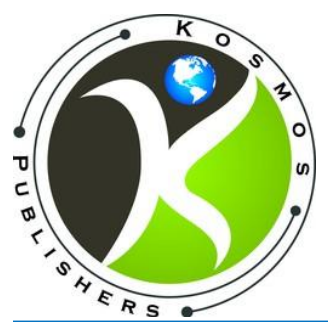

Research Article

\title{
Morphological and Phenological Investigation on Crocus chrysanthus subsp. punctatus from Turkey
}

\author{
Feyza Candan*
}

\begin{abstract}
Department of Biology, Faculty of Science and Letters, Manisa Celal Bayar University, Manisa/Turkey
\end{abstract}
Received Date: August 03, 2021; Accepted Date: August 30, 2021; Published Date: September 07, 2021;

"Corresponding author: Feyza candan, Department of Biology, Faculty of Science and Letters, Manisa Celal Bayar University, Manisa/Turkey. Email: feyzacandan2002@yahoo.com

\begin{abstract}
Crocus chrysanthus subsp. punctatus Candan \& Özhatay is one of the new taxa of Crocus chrysanthus (Herbert) Herbert. This new taxon distributes in West, South and inner parts of Anatolia and in south Europe. This plant descripted as a new taxon in the point of significant morphological differences related to its anther, pollen, seed and chromosome number. However, this taxon can be distinguished with its yellow flowers and yellow anthers with greyish black basal lobes, easily at the field. In this study, it is aimed to describe all morphological characteristics of the Crocus chrysanthus subsp. punctatus Candan \& Özhatay as regards mature plants with its colorful photographs in a detailed way. On the other hand, phenology of the taxon is explained with this investigation.
\end{abstract}

Keywords: Crocus chrysanthus subsp. punctatus; Morphology; Phenology;

\section{Introduction}

Iridaceae consists of 92 genera and 1800 species and mainly distributed in the Southern hemisphere continents as herbs with rhizomes, corms or bulbs (Mathew 1982, 1984, 1998, 2000). Crocus is one of the important taxon in this family known as 'Saffron'. Saffron stylus is very valuable used as a spice by weight. This genus has a commercially importance in the world in the point of its value as a spice and beautiful view of flowers for gardens in cold days (Mathew 1982, 2002).
Turkey especially Anatolia is the gene centre for the genus. Crocus is represented about 200 taxa of which most of them endemic to Turkey (Candan and Ozhatay, 2013; Kerndorff et al., 2013a; Rukšāns et al., 2013; Yüzbaşığlu et al., 2015; Harpke et al., 2017; Raca et al., 2017; Yüzbaşığlu, 2017).

There are some detailed investigations made about Crocus taxa distributed all over the world (Collins, 1937; Karasawa, 1942; Shorina, 1975; Rudall, 1990; 1992). However, after the book 'The Crocus' written (Mathew, 1982), different Crocus species have received attention on some ecological, anatomical, cytological, palynological and molecular studies (Işsk and Oybak Dönmez, 2006; Candan, 2007; Ş1k et al., 2008; Kandemir, 2009; Ş1k and Candan, 2009; Candan et al., 2009a, b; Candan and Özhatay, 2013; Kerndorff et al., 2013b, c; Candan, 2015a, b, c, d).

I studied about Crocus chrysanthus at my doctorate thesis that I found different forms of Crocus chrysanthus and completed my study in 2007 (Candan, 2007). I continued my studies between 2007-2011and after my doctorate thesis. According to all detailed field and laboratuary studies, Candan and Özhatay (2013) wrote the article about 7 new taxa of Crocus chrysanthus. One of these taxa were mentioned at that article is Crocus chrysanthus subsp. punctatus Candan \& Özhatay can be identified by looking at its greyish black lobed yellow anthers and yellow flowers. Therefore, the initial objective of this study was to investigate the morphology of new taxon Crocus chrysanthus subsp. punctatus in a detailed way with its original colorful photographs and its phenology. 


\section{Material and Methods}

C. chrysanthus subsp. punctatus material was collected from natural populations in flowering and seeding time. The populations of the plants examined are given below with the locality they deploy. The expression B2 is written before the locality is given in accordance with grid square system used in Flora of Turkey and The East Aegean Islands (Mathew, 1984).

The specimens were deposited in the herbarium ISTE (Istanbul Univ. Pharmacy Faculty Herbarium). Taxonomical description of the plant taxon followed Candan and Özhatay (2013). All the examinations were based on living and herbarium materials. The locality of the sample is given below.

Type:B2 Kütahya, Uşak-Aslanapa road, near Gediz, left parts of the road, 1185 m, 18 March 2005 F. Candan 86041 (Holotype:ISTE)

PARATYPE: B2 Kütahya, $10 \mathrm{~km}$ to Kütahya, $950 \mathrm{~m}$ (AEF 17106! :( Ankara University, Pharmacy Faculty Herbarium)

\section{Results}

\section{Morphological Peculiarities}

Corm ovoid veya subglobose, $0,5-2,3 \times 0,8-2,2 \mathrm{~cm}$, tunic coriceus. More rings with distinct tooth like prejections. Cataphyll creamy-yellow, (3)4-5. Prophyll absent. Bract ve bracteol not equal. Leaves 3-6(8), synanthous, shorter or longer than flowers in flowering time, green, $0,6-1,2(1,5)$ mm wide, papillose rarely scabrose. Flowers 1-4(5), yellow, yellowish orange, throat and perigon tube pale yellow, creamy white, yellow, Perigon tube (1)2,5-5,3(10,8) cm, at flowering time underground part $(0,1) 1,5-3 \mathrm{~cm}$, pubescent. Outer tepals $(0,4) 0,5-1,1 \times 1,8-3,2 \mathrm{~cm}$, inner tepals $0,4-1,1 \times 1,5-3,0 \mathrm{~cm}$. Filaments yellow, yellowish orange, orange; $3-9 \mathrm{~mm}$; pubescent or puberulent. Anthers yellow with blackish lobes (6)7-11, $9 \mathrm{~mm}$, basifixed, ekstrorse. Style divided into 3 fimbriate or expanded branches, yellowish orange, orange; 10 , 6-19(20) mm, longer than stamens. Capsula loculisid, 5-8x12$22 \mathrm{~mm}$. Seed pale reddish brown, brown, 1, 7-2, 4x (2, 8)3-4, $8(5,1) \mathrm{mm}$, elipsoid, raphe and caruncla distinct (Fig. 1-2).

\section{Phenological Peculiarities}

Crocus chrysanthus subsp. punctatus distributes in the wild places, near rocky slopes, open rocky fields, near Pinus nigra forests, This taxon is growing on the North slopes of the mountains and hills which has cold winds. The plants' flowering time period is from February to March mostly with Galanthus sp., Colchicum sp., Verbascum sp., Muscari sp. and Ornithogalum sp. Its seed maturing time is about June and July according to hotness and microclimate of the area. Most of the plants are growing from new corms which are divided from old ones but a few plants were seen developed from seeds at the field studies.

\section{Results and Discussion}

C. chrysanthus was described by W. Herbert in 1837 , collected by Frivaldsky in Rumelia. It is distributed in the Balkans and E. Romania. Mathew wrote a magnificent monograph 'The Crocus' (1982). However; the genus Crocus was previously revised by Mathew (1984) for the Flora of Turkey and The East Aegean Islands. The discussion note under $C$. chrysanthus account cited in the Flora of Turkey and The East Aegean Islands is as follows: 'A variable plant, possible consisting of more than one taxon but detailed field studies are needed to determine the status of the various cytotypes'.

The Crocus genus and especially biflori serie are complex and problemetic systematic categories. According to Mathew (1984), the new species falls into series Biflori. Crocus chrysanthus belongs to this serie. On the other hand, there was an important phenotypic variation, was seen on $C$. chrysanthus (Mathew, 1982; 1984).

I (2007) determined three forms of C.chrysanthus with different cytotypes $(2 \mathrm{n}=8,12,20+2 \mathrm{~B})$ during my doctorate thesis field studies. After this study, I continued my investigations as examining more populations in Anatolia. The results of those detailed studies including morphology, anatomy, cytology, palynology and seed micromorphology provide evidence that variation does correlate with anther and flower colors, chromosome numbers, pollen grain features and seed surface micromorphology. After these studies, Candan and Özhatay (2013) revealed Crocus chrysanthus sensu lato with 4 subspecies (C. chryasanthus subsp. chrysanthus, C.chrysanthus subsp. punctatus, C. chrysanthus subsp. kesercioglui, C. chrysanthus subsp. sipyleus) and 3 varieties (C. chrysanthus subsp. chrysanthus var. chrysanthus, C. chrysanthus subsp. chrysanthus var. bicoloreus, $C$. chrysanthus subsp. chrysanthus var. atroviolaceus).

The most detailed measurements were given in the point of Crocus chrysanthus with Flora of Turkey and The East Aegean Islands (1984). Nevertheless, these knowledge are not clarifying the taxon clearly. Some information given about $C$. chrysanthus sensu lato (2013), but more detailed original photographs regarding morphological features of $C$. chrysanthus subsp. punctatus were given with this investigation. This study is the first study gives the information about all the significance characters of $C$. chrysanthus subsp. punctatus with their colorful orginal photographs (Fig.1-2). However, $C$. chrysanthus subsp. punctatus can be distinguished from the other taxa of $C$. chrysanthus by its greyish black basal lobes with yellow anthers easily. These photographs can be used to seperate this taxon form the other $C$. chrysanthus taxa clearly. 


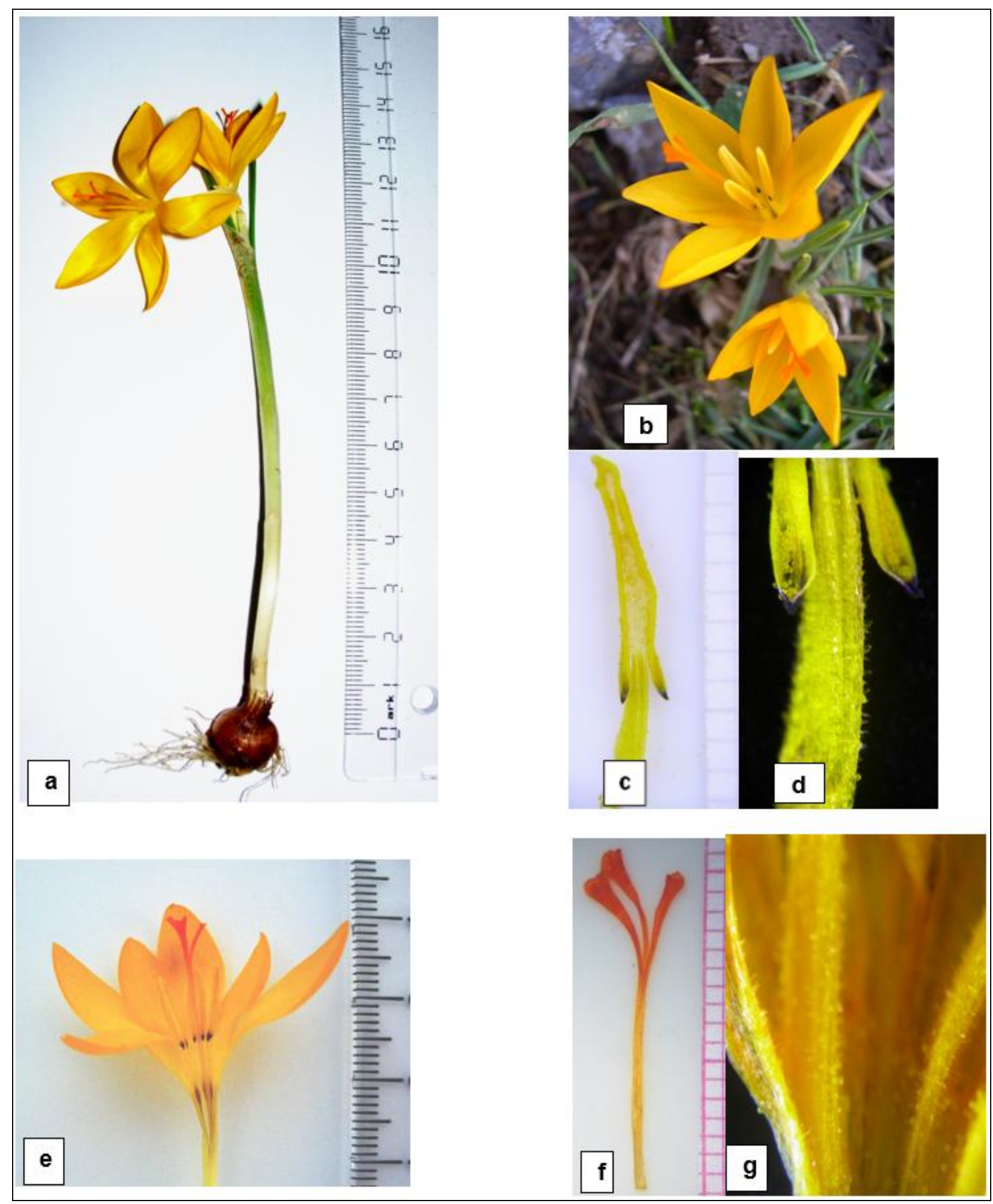

Figure 1: a. General view of C. chrysanthus subsp. punctatus,

b. Close view of flower,

c-d. Close view antherse,

e. General view of anthers and styleus,

f. Close view of stylus,

g. Close view of perigon. 


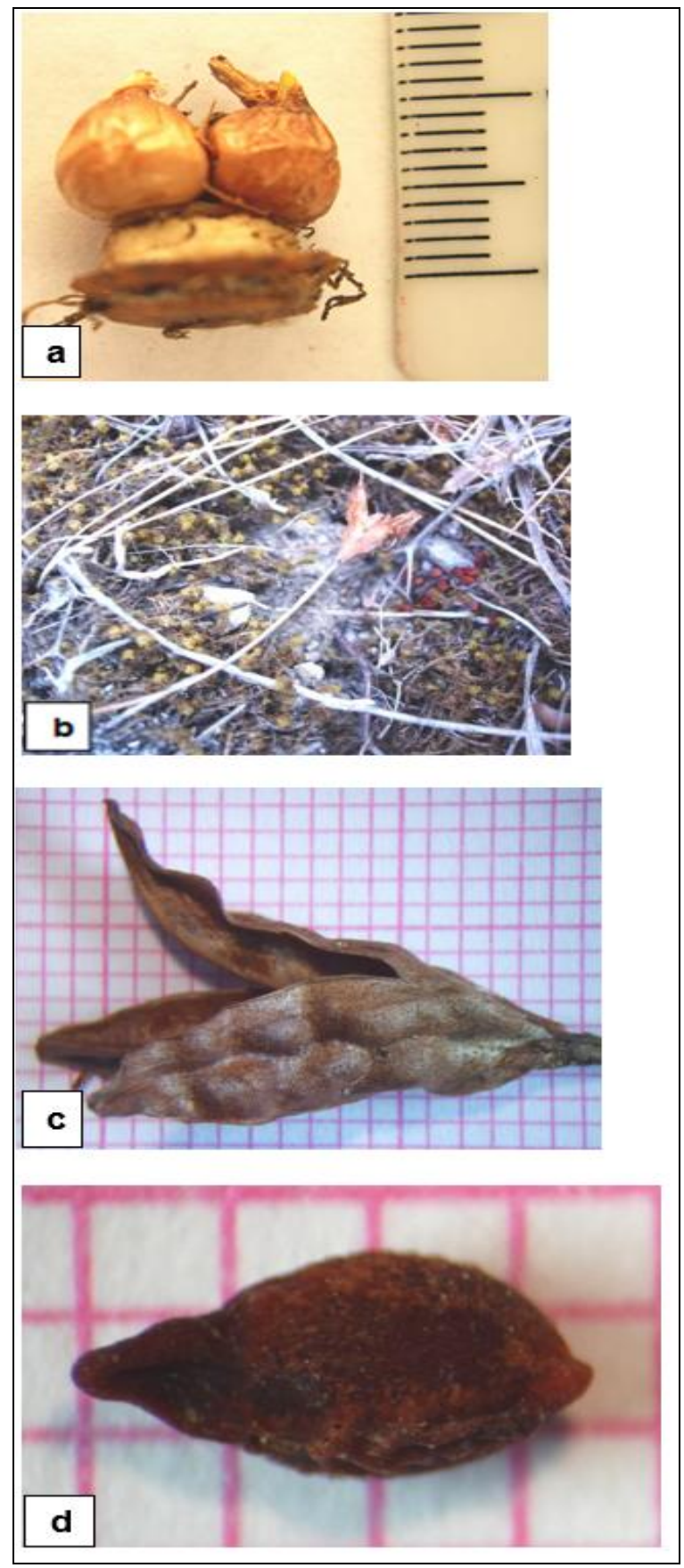

Figure 2: a. Close view of corm,

b. General view of fruit and seeds,

c. Close view of fruit,

d. Close view of seed.

\section{Conclusion}

As a conclusion, it can be clearly said, morphological characters of flower are very important for Crocus chrysanthus sensu lato taxonomy. In the studied taxon according to this investigation, some differences with acceptable taxonomical significance were mentioned with more important colored photographs for making it easy to identify the taxon, easily at the field.

\section{Acknowledgement}

I am grateful to Manisa Celal Bayar University for financial support (Project No: 2004-037) of some part of this study. 


\section{References}

1. Candan F (2007) Morphological, anatomical, cytological and palynological investigations on $C$. ancyrensis, $C$. sieheanus, $C$. chrysanthus and $C$. flavus taxa of the genus Crocus L... PhD thesis. Natural and Applied Sciences Institute, Celal Bayar University, Manisa, Turkey.

2. Candan F, Şık L, Kesercioğlu T (2009) Cytotaxonomical Studies on some Crocus L. Taxa in Turkey. African Journal of Biotechnology, 8:4374-4377.

3. Candan F, Kesercioğlu T, Şık L (2009) Micromorphological Investigations on Pollen Samples of Four Yellow Flowered Taxa of Crocus L. (Iridaceae) from Turkey. Journal of Applied Biological. 3:56-59.

4. Candan F, Özhatay N (2013) Crocus chrysanthus s. lato (Iridaceae) in Turkey. Annales Botanici Fennici, 50:423430.

5. Candan F (2015) Morphological and Leaf Anatomical Investigations on 2 Yellow Flowered Endemic Taxa of Crocus L. (Crocus ancyrensis, Crocus siehenaus) from Turkey. International Journal of Agriculture, Forestry and Fisheries. 3:93-98.

6. Candan F (2015) b. Comparative Morphological and Leaf Anatomical Investigations of Crocus flavus Weston from Turkey. International Journal of Agriculture, Forestry and Fisheries. 3:99-104.

7. Candan F (2015) c: Morphological Investigations on a New and Endemic Saffron (Crocus chrysanthus subsp. sipyleus) from Turkey. International Journal of Agriculture, Forestry and Fisheries. 3:137-141.

8. Candan F (2015) d: Morphological Characteristics and Phenology of the New Taxon Crocus chrysanthus subsp.chrysanthus var. chrysanthus from Turkey, International Journal of Plant Science and Ecology, 1:196200.

9. Candan F (2015) e. Comparative Morphological Investigation on Seeds of Some Crocus L. Taxa from Turkey. International Journal of Plant Science and Ecology, 1:201-207.

10. Collins EJ (1937) Leaf Form and Structure. In: The Genus Crocus Proc. Linn. Soc., London (Abstract), 149:116-118.

11. Harpke D, Kerndorff H, Raca I, Pasche E (2017) A new Serbian endemic species of the genus Crocus (Iridaceae). Biologica Nyssana, 8:07-13.

12. Ișık S, Oybak Dönmez E (2006) Pollen Morphology of Some Turkish Crocus L. (Iridaceae) Species. Acta Biologica Cracoviensia, Series Botanica 48:85-91.

13. Kandemir N (2009) Morphology, Anatomy and Ecology of Critically Endangered Endemic Crocus pestalozzae Boiss. (Iridaceae) in North-West Turkey. Bangladesh
Journal of Botany, 38:127-132.

14. Karasawa K (1942) On the leaf structures of Crocus observed in transverse sections and their chromosome numbers. Bot. Mag. Tokyo, 56:19-25.

15. Kerndorff H, Pasche E, Blattner FR, Harpke D (2013) a: Fourteen new species of Crocus (Liliiflorae, Iridaceae) from west, southwest and south-central Turkey. Stapfia 99:145-158.

16. Kerndorff H, Pasche E, Blattner FR, Harpke D (2013) b: A new species of Crocus (Liliiflorae, Iridaceae) from Turkey. Stapfia 99:141-144.

17. Kerndorff H, Pasche E, Blattner FR, Harpke D (2013) c: Crocus biflorus Miller (Liliiflorae, Iridaceae) in AnatoliaPart IV. Stapfia. 99:159-186.

18. Mathew B (1982) The Crocus: A revision of the genus Crocus (Iridaceae). B.T. Batsford LTD.

19. Mathew B (1984) Crocus:-In Davis, P.H. (ed.), The Flora of Turkey and The East Aegean Islands. 8:413-438, Edinburgh University.

20. Mathew B (1998) Crocus kerndorffiorum. Curtis's Bot. Mag, 15:120-124.

21. Mathew B (2000) Crocus. -In Güner, A. et al. (eds), Flora of Turkey and the East Aegean Islands. Edinburgh Univ. Pres, 11:271-274.

22. Mathew B (2002) Crocus Up-date. The New Plantsman. 1:44-56.

23. Raca I, Ljubisavljević I, Jušković M, Ranđelović N, Ranđelović V (2017) Comparative anatomical study of the taxa from series Verni Mathew (Crocus L.) in Serbia. Biologica Nyssana, 8:15-22.

24. Rudall P (1990) Comparative leaf morphogenesis in Iridaceae. Bot. Jahrb. Syst, 112:241-260.

25. Rudall P (1992) Anatomy of Flowering Plants. Cambridge University Press.

26. Rukšāns J (2013) Seven new Crocuses from the Balkans and Turkey. Alpine Gardener, 81:188-193.

27. Shorina NI (1975) Leaf Structure in some saffrons in association with the evolution of the genus Crocus L. Byull. Mosk. Obsch. Ispyt. Prir, Otdel Biol, 80:117-125.

28. Şık L, Candan F, Soya S, Karamenderes C, Kesercioğlu T et al. (2008) Genetic variation among Crocus L. species from Western Turkey as revealed by RAPD and ISSR markers. Journal of Applied Biological Sciences, 2:73-78.

29. Şık L, Candan F (2009) Ecological properties of some Crocus taxa in Turkey. African Journal of Biotechnology, 8:1895-1899.

30. Yüzbaşıŏlu S, Aslan S, Özhatay N (2015) Crocus thracicus (Iridaceae), a new species from north-western Turkey. Phytotaxa 197:207-214.

31. Yüzbaşığlu S (2017) Crocus tuna-ekimii (Iridaceae), a new species from Turkey. Phytotaxa, 314:110-116.

Citation: Candan F (2021) Morphological and Phenological Investigation on Crocus Chrysanthus Subsp. punctatus from Turkey. Adv Agri Horti and Ento: AAHE-156. 